How to cite: Milian, N., Mitea, A., Blaga, C., Pașol, A., Câmpean, O. (2020) Favorable Conditions for Avalanche Triggering During 2018-2019 Winter. 2020 "Air and Water - Components of the Environment" Conference Proceedings, Cluj-Napoca, Romania, p. 283-290, DOI: 10.24193/AWC2020_26.

\title{
FAVORABLE CONDITIONS FOR AVALANCHE TRIGGERING DURING 2018-2019 WINTER
}

\author{
Narcisa MILIAN ${ }^{1}$, Adela MITEA ${ }^{1}$, Cristina BLAGA ${ }^{1}$, Adrian PAȘOL ${ }^{1}$, Ovidiu \\ CAMPEAN $\boldsymbol{N}^{1}$
}

\author{
DOI: 10.24193/AWC2020_26
}

\begin{abstract}
The paper presents and analyzes the variations of the meteorological and specific snow parameters, which favored avalanches occurence during 2018-2019 winter, in the area monitored by the National Administration of Meteorology. The analyzed parameters are measured by daily observations and weekly measurements at the weather stations Bâlea-Lac, Omu Peak, Sinaia and Predeal, Parâng, Țarcu, Semenic, Vlădeasa, Iezer, Călimani, Ceahlău, in order to use them for a better avalanche risk estimation and the diminution of their effects on the environment and people. The favorable conditions for triggering the avalanches were due to the significant snowfall, high temperature values or their sudden increase, as well as the transformations that take place inside the snow layer, when unstable structures are formed.
\end{abstract}

Keywords: avalanche, ground pressure, temperature, snowfall

\section{INTRODUCTION}

Nivological season 2018-2019 season started on November 15, 2018 at all eleven stations within nivological program; Bâlea-Lac, Omu Peak, Sinaia and Predeal, Parâng, Țarcu, Semenic, Vlădeasa, Iezer, Călimani, Ceahlău.

During 2019, a total of 2948 observations were made, starting from January 1 and until April 30 (in Predeal, Sinaia, Parang, Iezer, Vlădeasa, Semenic), May 15 (in Călimani, Ceahlau Toaca), May 31 (Țarcu, Bâlea-Lac, Omu Peak). Also, 211 surveys and stratigraphic profiles of the snow layer have been performed.

Based on the collected data, daily avalanche risk bulletins were issued and posted on the official site of the National Meteorological Administration and sent to: Dispatcher of the Ministry of Environment, Mountain Rescue Teams (Salvamont), prefectures, county councils in the monitored area, mass media.

Maximum snow thickness in the meteorological stations platform was recorded at Bâlea-Lac on the date of February 13, 2019 and had the value of $300 \mathrm{~cm}$. At the other meteorological stations, the highest measured values were of: 174 at Țarcu Peak (12 and 13.02.2019), $146 \mathrm{~cm}$ at the Omu Peak (20.04.2018), $127 \mathrm{~cm}$ at Sinaia (30.01 and 01.02.2019), $115 \mathrm{~cm}$ at Călimani (23.02.2019), $111 \mathrm{~cm}$ at Semenic (24 and 25.02.2019), $102 \mathrm{~cm}$ at Parâng (31.01.2019), $92 \mathrm{~cm}$ at Ceahlău (25.01.2019), 84 $\mathrm{cm}$ at Vlădeasa 1800 (15.01.2019) and $63 \mathrm{~cm}$ at Predeal (15.02.2019) (Fig.1).

\footnotetext{
${ }^{1}$ SRPV Sibiu, CMR Transilvania-Sud, 550003 Sibiu, Romania; ${ }^{2} \mathrm{PhD}$ candidate at Şcoala Doctorală de Ştiinţe, Craiova University, Romania; e-mail: narcisa.milian@gmail.com
} 


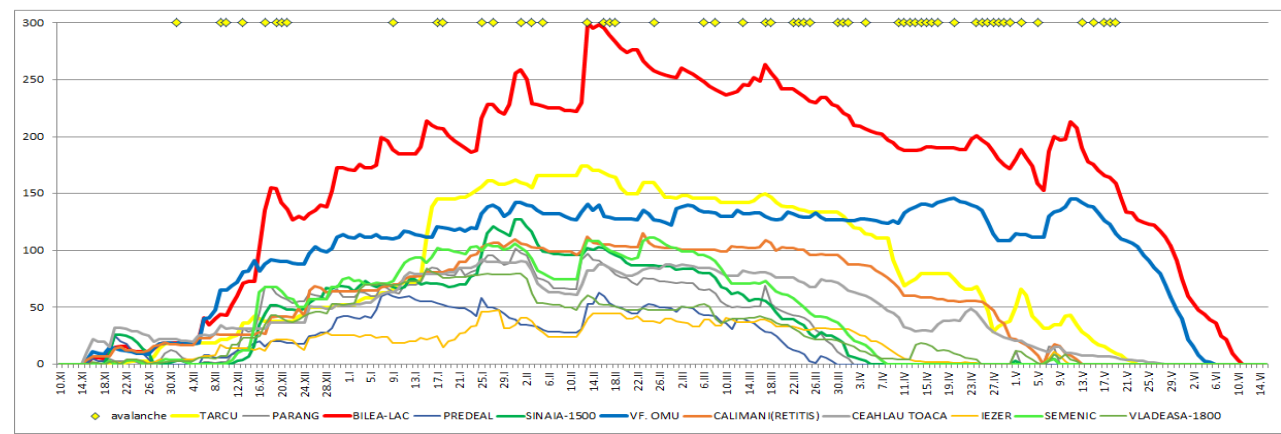

Fig. 1. 2018-2019 winter season - Snow layer variation and days with avalanche records at all the meteorological stations within nivological program

Annual graphics of daily meteorological parameters show snow thickness variation and amount of precipitation, with important snow accumulation, as well as alternation of colder with warmer periods, favoring snow melting and surface moisture, thus increasing the risk of triggering avalanches (Fig. 2-4).

At Bâlea-Lac, several avalanches were recorded, most of them during the periods: 0921.12.2018, 17-18.01.2019, 25-31.01.2019, 16-25.02.2019 and 13-22.03.2019 (Fig. 2).

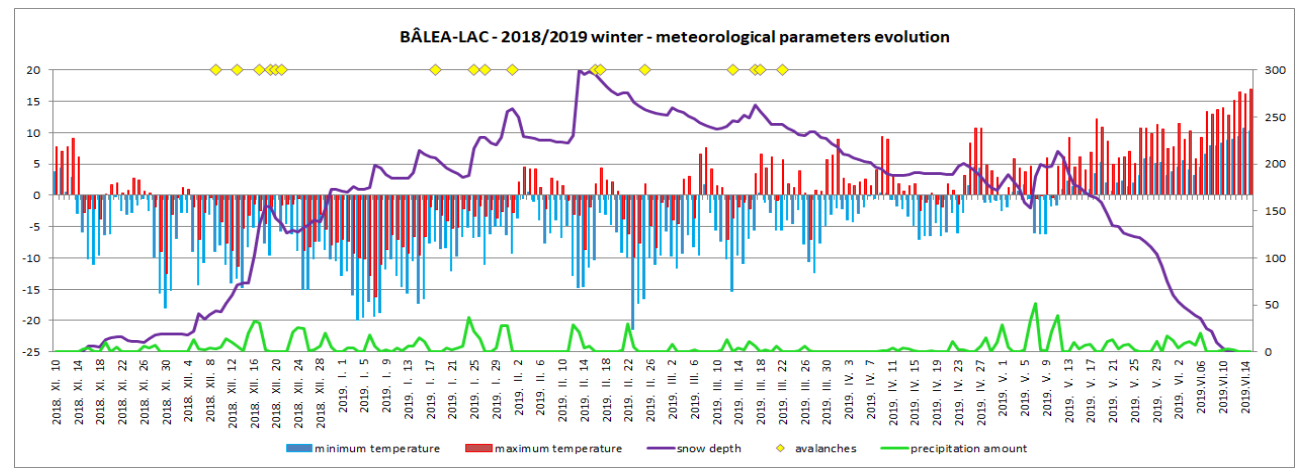

Fig. 2. 2018-2019 winter season - daily meteorological parameters measured at Bâlea-Lac meteorological station

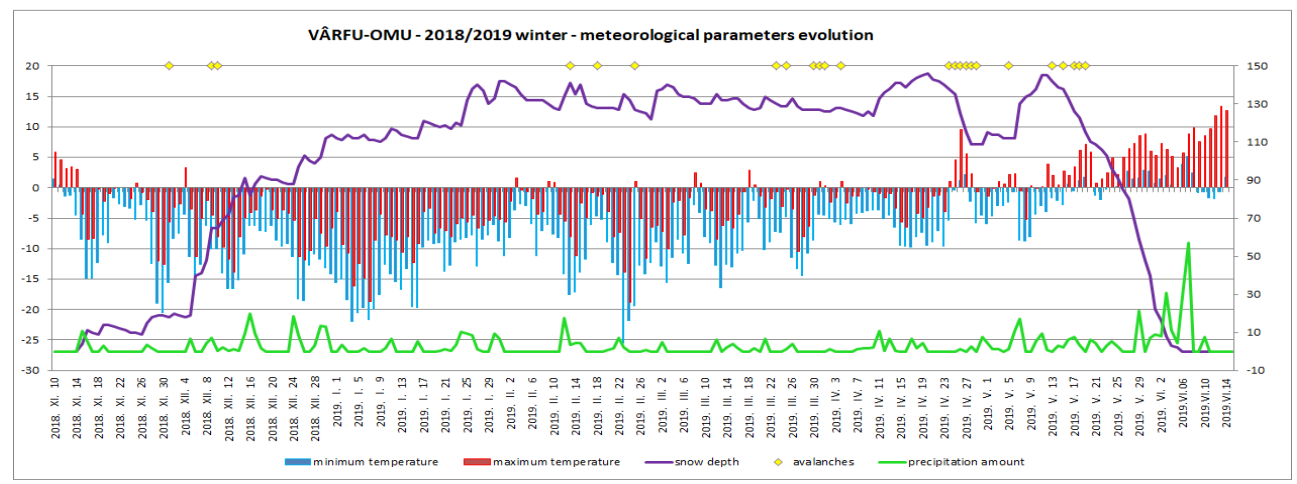

Fig. 3. 2018-2019 winter season - daily meteorological parameters measured at Vârfu-Omu meteorological station 
At Vârfu-Omu meteorological stations, avalanches occurred mostly during the following periods: 13-20.02.2019, 23.03-03.04.2019, 24-29.04.2019, 13-19.05.2019 (Fig. 3) and at Iezer meteorolgical station avalanches were recorded during 0608.03.2019, 22-24.03.2019, 10-17.04.2019 (Fig. 4)

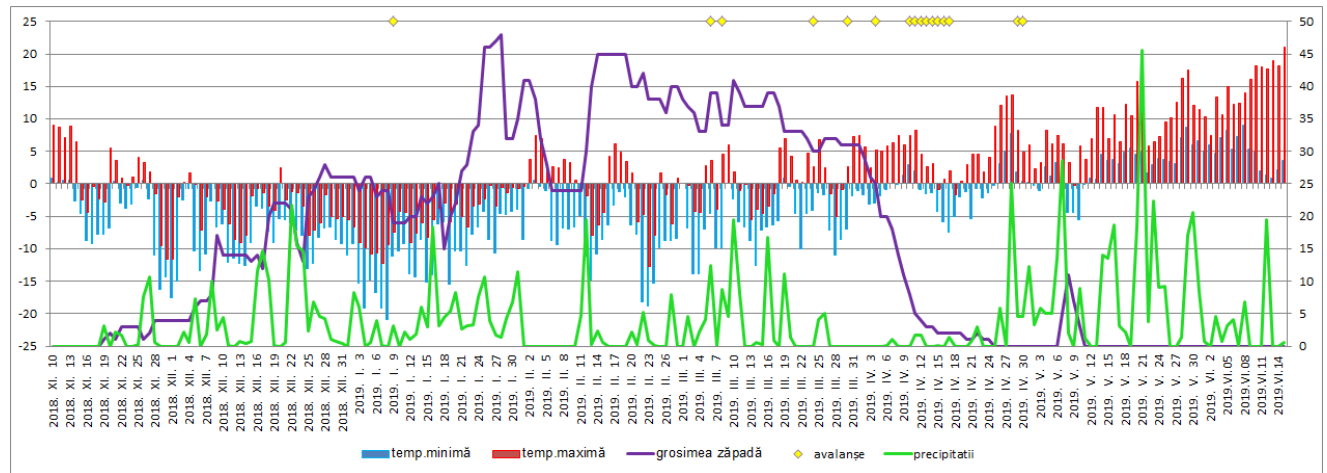

Fig. 4. 2018-2019 winter season - daily meteorological parameters measured at Iezer meteorological station

\section{SYNOPTIC CONDITIONS FOR AVALANCHE PERIODS}

\subsection{January 13 to 17,2019}

During the period, the Icelandic Trough High influenced our area, while Azores High was approaching over the country. At $500 \mathrm{hpa}$, the associated Icelandic Trough was already active (Fig. 5). At the level of $850 \mathrm{hPa}$, isotherm value ranged from -10 in January 13 to 0 degrees in January 17 (Fig. 5).

Avalanches were reported most on Bâlea-Lac, were snow depth increased from 185 to $214 \mathrm{~cm}$ (from January 13 to 15 ). Maximum and minimum temperatures were low (-17,6 and 6,6 in January 16) until January 17, when they increased to $-7,7$ and $-1,8$ degrees.
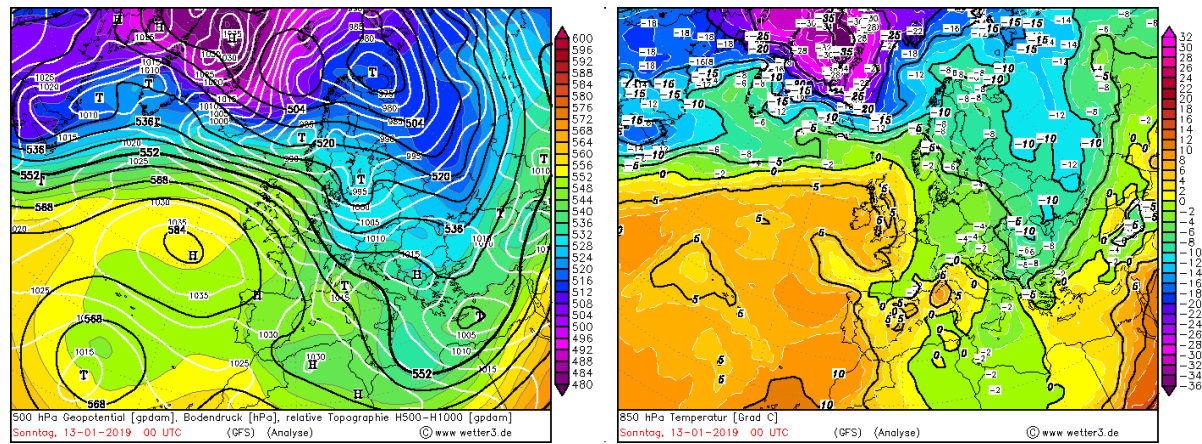

Fig. 5. 2019.01.13, at 00 UTC - NCEP numerical model-reanalysis.

Ground-level pressure, absolute topography and 500hPa geopotential; $850 \mathrm{hPa}$ geopotential and temperature 


\subsection{January 25 to February 01, 2019}

All the period, the Icelandic Low was active over Romania, with correspondent structure in altitude, with ground pressure values around $1005-1010 \mathrm{mb}$ and geopotential values at $500 \mathrm{hPa}$ of 540 to $548 \mathrm{dmgp}$ (Fig. 6). At the level of $850 \mathrm{hPa}$, isotherm value ranged from -5 to 4 degrees on January 28 and 29, then back to 0 degrees.

Though temperatures did not have significant variations during this period, the important amount of snow that felt at Bâlea-Lac $(40 \mathrm{~cm}$, from January 24 to 26 and $39 \mathrm{~cm}$ from January 29 to February 1), offered the optimal conditions for avalanche release.
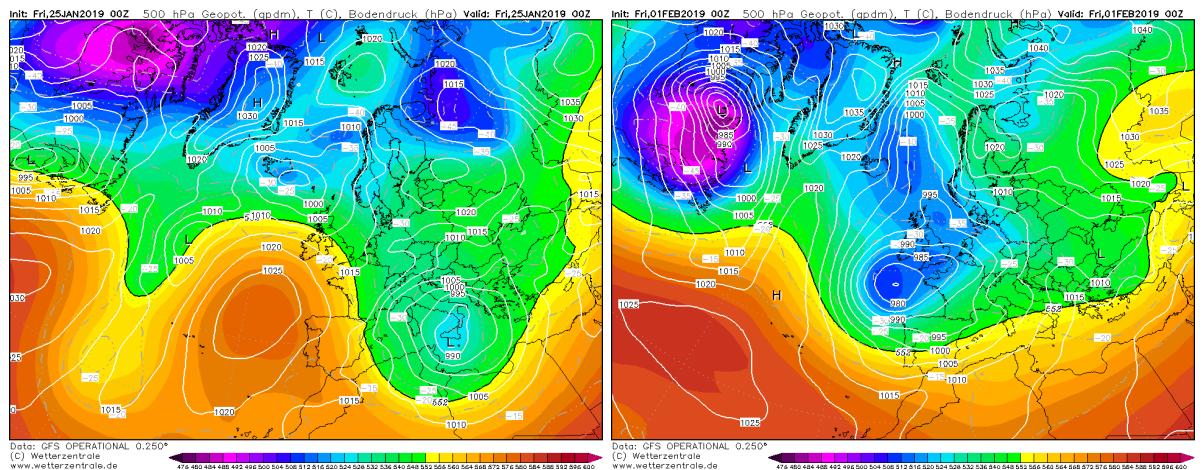

Fig. 6. 2019.01.25 and 02.01, at 0O UTC - NCEP numerical model - reanalysis. Ground-level pressure, absolute topography and $500 \mathrm{hPa}$ geopotential

\subsection{February 13 to 25,2019}

The period was dominated by the Azores High, with ground pressure values up to $1040 \mathrm{mb}$, with associated altitude structure at $500 \mathrm{hPa}$. During February 23 and 24 , an Icelandic Trough, with low geopotential values, down to $532 \mathrm{dmgp}$ and very cold air (-35 degrees) passed over the country (Fig. 7).
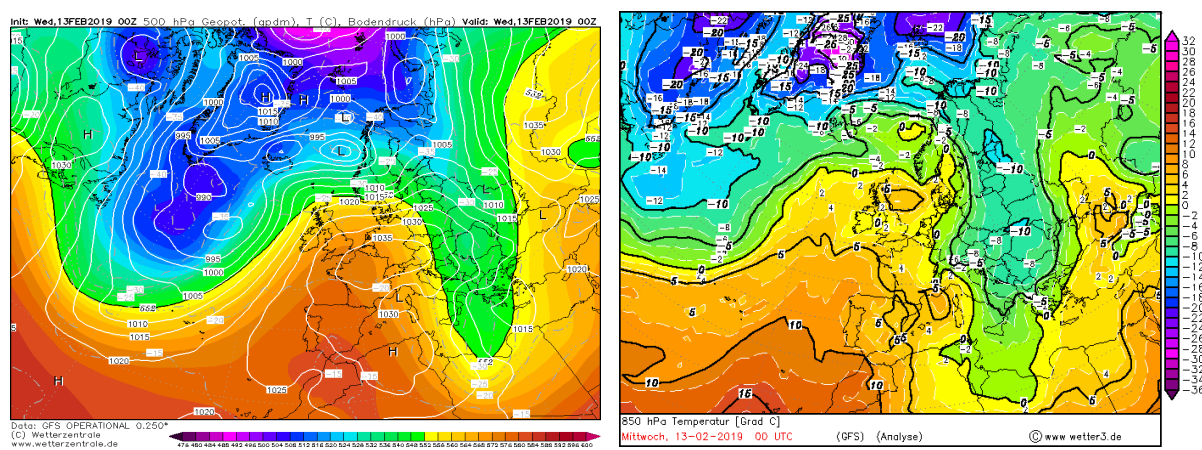

Fig. 7. 2019.02.13, at 00 UTC - NCEP numerical model reanalysis. Ground-level pressure relative topography, 500hPa geopotential; 850 hPa geopotential and temperature 
The values of $850 \mathrm{hPa}$ level isotherm increased from February 13 (-10 degrees) to 4 degrees on February 17 (Fig. 7) and remained at that value until February 20. Then, with the associated trough structure and cold air intrusion, decreased to -15 degrees until the end of the interval.

Again, at Bâlea-Lac felt a huge amount of snow $-70 \mathrm{~cm}$ in one day, reaching the highest snow value for this winter $(300 \mathrm{~cm}$ in February 13). With the increasing temperatures in the next days, reaching positive values, several avalanches occurred in the area (Fig. 7). Though the amount of new snow was considerable lower, several avalanches occurred in Bucegi Mountains, near Vârfu Omu meteorological station.

\subsection{March 13 to 18,2019}

While ground pressure field was high at the beginning of the interval, due to the Azores Ridge (ground pressure values around $1020 \mathrm{mb}$ ), then, with the intrusion of the Icelandic Trough, they decreased to $1015 \mathrm{mb}$. On middle troposphere, already acted the Icelandic Trough, with geopotential values around $540 \mathrm{dmgp}$ and temperatures from -30 to -25 degrees. Isotherm at $850 \mathrm{hPa}$ level values around -5 degrees, increasing to the end up to 8 degrees (Fig. 8).

A small amount of fresh snow felt at the beginning of the interval, when low temperatures were recorded, The, temperatures increased, up to 6,5 degrees in March 18 , and several melting avalanches occurred, especially in Făgăraș Mountains, at Bâlea-Lac.
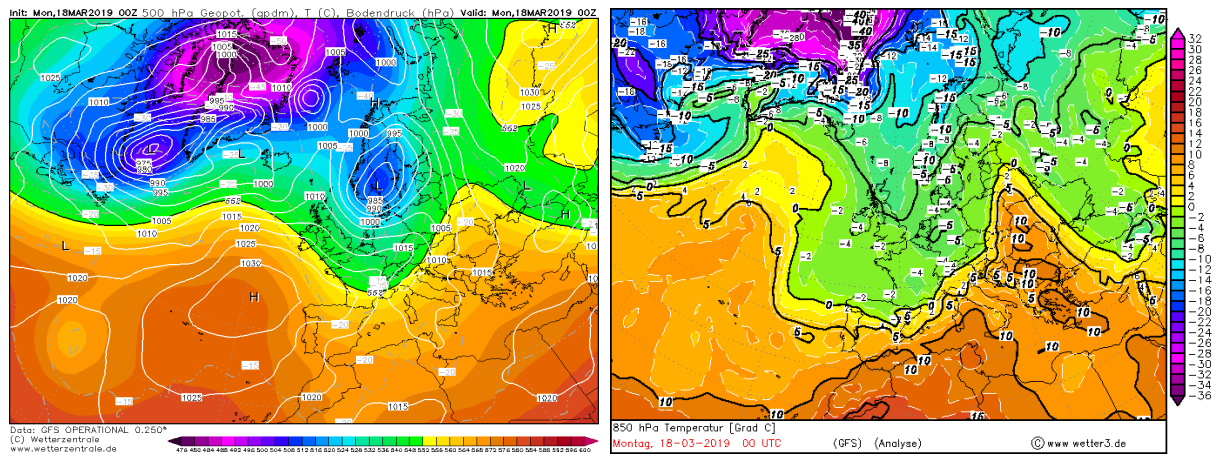

Fig. 8. 2019.03.18, at 00 UTC - NCEP numerical model-reanalysis. Ground-level pressure, absolute topography and $500 \mathrm{hPa}$ geopotential

\subsection{March 22 to April 04, 2019}

The period was characterized by the presence of the Azores High, with ground pressure values of $1025-1030 \mathrm{mb}$ and associated altitude structure at $500 \mathrm{hPa}$, where geopotential values decreased from 572 to $560 \mathrm{dmgp}$ (Fig. 9). The values of $850 \mathrm{hPa}$ level isotherm varied from 0 to 6 degrees (in April 01) - (Fig. 9).

Maximum temperatures were mostly positive at meteorological stations from altitudes up to $2100 \mathrm{~m}$, but remain mostly negative at Vârfu-Omu (2504 m). Though 
around 0 degrees, due to the insolation, several melting avalanches occurred also in the Vârfu-Omu meteorological station area, as well at Bâlea-Lac and Iezer stations.
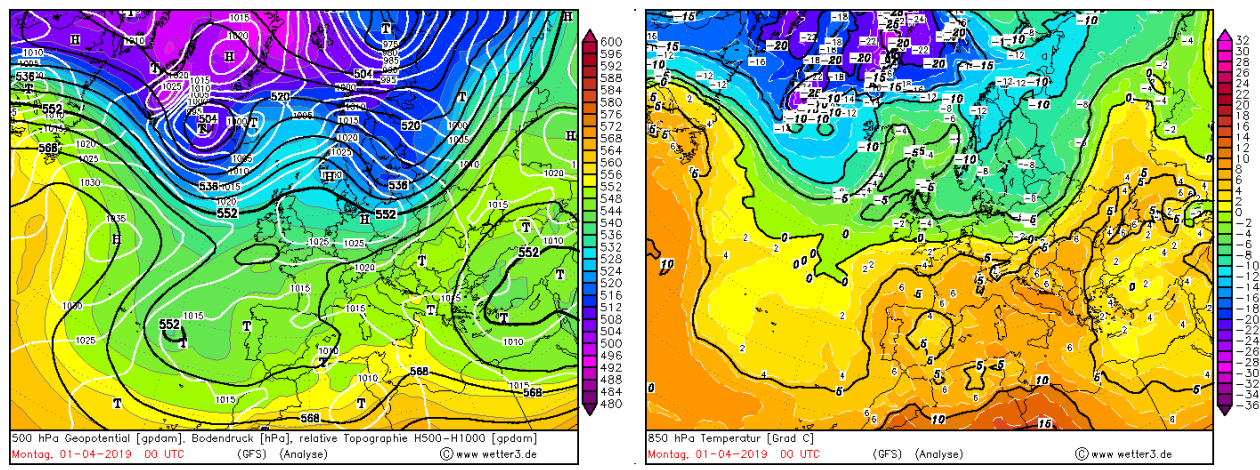

Fig. 9. 2019.04. 01, at 00 UTC - NCEP numerical model-reanalysis. Ground-level pressure, absolute topography and 500hPa geopotential; $850 \mathrm{hPa}$ geopotential and temperature

\subsection{April 10 to 17,2019}

Up to April 15, a low-pressure ground field, with values of 1010 to $1015 \mathrm{mb}$, persisted over the country, with correspondent low geopotential of 548 to $552 \mathrm{hPa}$ in the middle troposphere. From April 15 to 17, Scandinavian Ridge descended over the area, ground pressure increased up to $1025 \mathrm{mb}$ and geopotential values at 500 $\mathrm{hPa}$ up to $568 \mathrm{dmgp}$. In lower troposphere, the $850 \mathrm{hPa}$ isotherm decreased from 6 (in April 10) to 0 degrees (April 17) (Fig.10).

Several melting avalanches were recorded around at Iezer station, were daytime temperatures were positive, reaching up to 8.3 degrees. Some of the night temperatures were also positive.
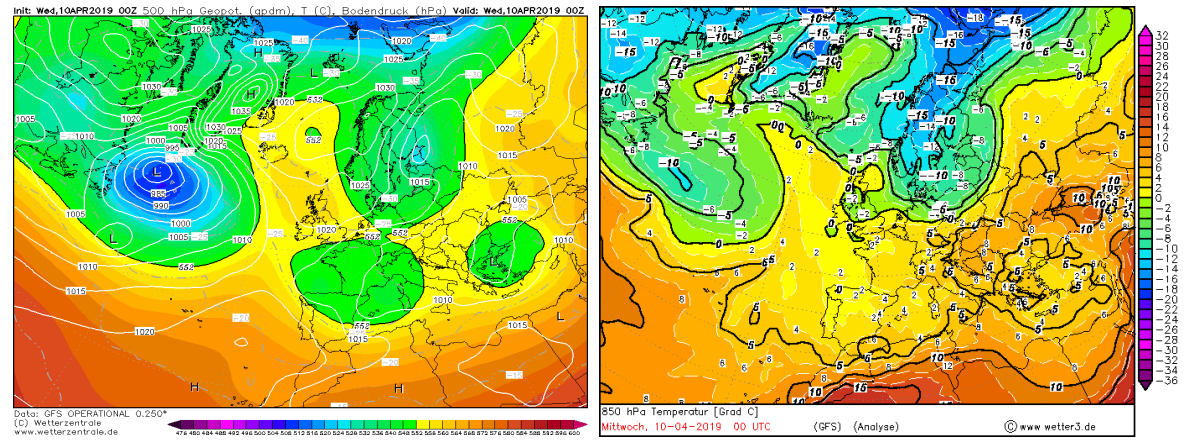

Fig. 10. 2019.04.10, at 00 UTC - NCEP numerical model-reanalysis.

Ground-level pressure, absolute topography and 500hPa geopotential; 850 hPa geopotential and temperature 


\subsection{April 24 to May 19, 2019}

Until April 28, the Azores Ridge persisted over the country, with ground pressure field values around $1025 \mathrm{mb}$ and associated middle level structure; then, up to the end of the period, ground pressure decreased to $1005 \mathrm{mb}$, due to the intrusion of a northern trough. In lower troposphere, the $850 \mathrm{hPa}$ isotherm had high values, from 8 degrees in April 24 to 12 degrees in April 27, than fell to 4 degrees (on May 02) and remained around $4 \ldots 6$ degrees until the end (Fig. 11).

With positive daytime temperatures recorded at all meteorological stations, reaching 10.7 degrees at Bâlea-Lac, 9,5 degrees at Vârfu Omu and 13,7 degrees at Iezer, snow melting and decreasing of height continued, as well as melting avalanches occurrence, that were recorded almost every day at Vârfu-Omu meteorological station.
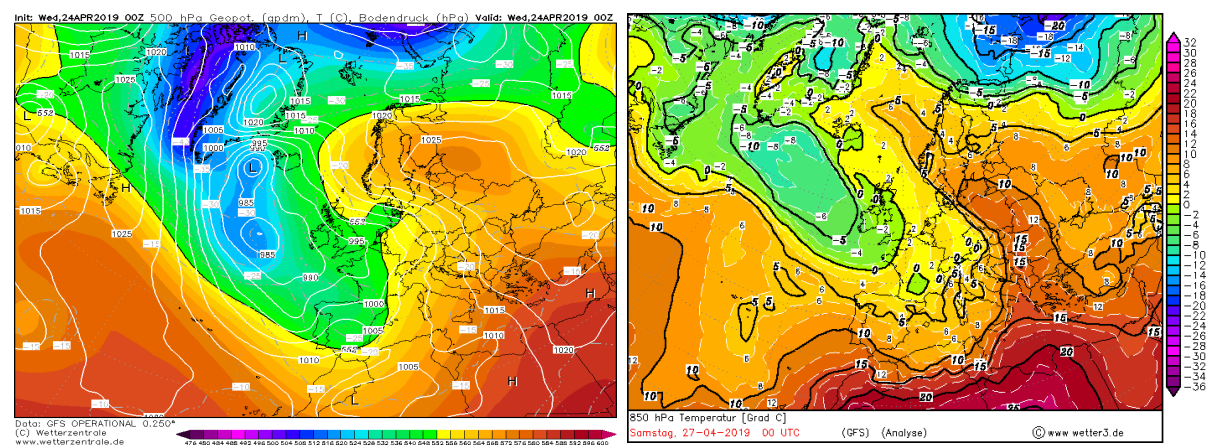

Fig. 11. 2019.04.27, at 00 UTC - NCEP numerical model - reanalysis.

Ground-level pressure, absolute topography and 500hPa geopotential; 850 hPa geopotential and temperature

\section{CONCLUSIONS}

In Romania, snow measurements and avalanche monitoring are made only by the National Administration of Meteorology. Though almost every winter avalanche synoptic conditions were studied since the beginning of nivological program, for Făgăraș and Bucegi Mountains, the extended measurements network offered a great opportunity to begin snow and avalanche studies all around the Carpathians.

As in the other winter seasons (Milian, 2016, 2019; Grecu, 2017), during 20182019, avalanches occurred all over the mountains, under different synoptic conditions and in every month. Most common avalanche triggering conditions remained important snowfall, fast increasing and positive temperatures.

With the extending of observational network at most of the mountain meteorological stations, snow and avalanche survey and avalanche risk estimation have made important steps forward, in order to prevent and avoid any human life loss, massive accidents with significant economic damage. 


\section{REFERENCES}

1. ***, Bilanţul nivologic al sezonului de iarnă - publicaţie anuală, începând din 2004, Administraţia Naţională de Meteorologie, Bucureşti

2. $\quad * * *$, Buletinul nivometeorologic - arhiva, Serviciul Regional de Prognoză a Vremii Sibiu

3. http://www.wetter3.de, accesed on January 17, 2019

4. Hansen C., Underwood S.J, (2012), Synoptic Scale Weather Patterns and Size-5 Avalanches on Mt. Shasta, California, Northwest Science, 86, 329-341

5. Höller P, (2009), Avalanche cycles in Austria: an analysis of the major events in the last 50 years, Natural Hazards, 48, 3, 399-424

6. Jaedicke C, Bakkehøi S, (2007), Climate database for avalanche consulting and warning in Norway, Cold Regions Science and Technology, 47, 1-2, 171-179

7. Fitzharris B.B, (1987), A climatology of major avalanche winters in Western Canada, Atmosphere-Ocean, 25: 2, 115-136

8. McClung D, Schaerer P, (1993), The Avalanche Handbook

9. Milian N., Pașol A., (2016), Synoptic Avalanche Triggering Conditions during 20142015 Winter, Air and Water - Components of the Environment Conference Proceedings 306-313, DOI: 10.17378/AWC2016_39

10. Grecu C., Pașol A., Milian N., Reckerth U. (2017), Synoptic Conditions Generating Important Snowfalls and Their Relation with Avalanches in 2015-2016 Winter; 379386, DOI: 10.24193/AWC2017 48

11. Milian, N. (2019), 2017-2018 Winter - Favorable Avalanche Conditions in Southern Carpathians, Air and Water - Components of the Environment Conference Proceedings, 399-406, DOI: 10.24193/AWC2019_39. 